Artigo recebido em

08/09/2014

Aprovado em

$14 / 10 / 2014$

FRANCISCO

ÂNGELO BRINATI

Universidade Federal de São João del-Rei chicobrinati@yahoo. com.br

Doutorando em Comunicação Social pela Universidade do Estado do Rio de

Janeiro (UERJ).

Professor de

Comunicação Social da Universidade Federal de São João del-Rei (UFSJ)
Estudos em Jornalismo e Mídia

Vol. 11 No 2

Julho a Dezembro de 2014

ISSNe 1984-6924

\section{Seleção Brasileira, identificação nacional e imprensa: A Representação do "Mineiratzen" na Folha de S. Paulo e em O Globo'}

Francisco Ângelo Brinati

Resumo

O esporte, entre as suas diversas variantes, também é meio de expressão das construções imaginárias acerca da identidade nacional. $\mathrm{O}$ futebol atua como um elemento aglutinador de raças e classes e é uma importante maneira de influenciar a visão que o brasileiro tem de si próprio. No Brasil, a seleção funciona como instrumento unificador de nação, representante da cultura nacional. O trabalho, um estudo sobre Comunicação e Esporte, pretende fazer uma análise do discurso dos jornais impressos O Globo e Folha de São Paulo no dia seguinte à derrota do selecionado nacional para a Alemanha na Copa do Mundo de 2014. Busca-se, uma vez que se percebera o vínculo simbólico entre o conceito de nação e o desempenho da seleção nacional de futebol, entender como foram construídas as representações da equipe e os jogadores diante do revés sofrido dentro de campo.

Palavras-chaves

Imprensa, Representação, Discurso, Seleção Brasileira, Copa do Mundo.

\section{Abstract}

The sport, among its many variants, is also means of expression of imaginary constructions about national identity. Football acts as a uniting element of races and classes and is an important way to influence the vision that the Brazilian has of itself. In Brazil, the selection works as a unifying instrument of nation, representative of the national culture. The work, a study on communication and sport, intends to make a discourse analysis of the newspapers $O$ Globo and Folha de São Paulo the day after the defeat of the selected national Germany in the World Cup of 2014. Search yourself, once you understand the symbolic link between the concept of nation and the performance of the national soccer team, understand how the representations were built the team and players before the setback suffered in the field.

Keywords

Press, Impersonation, Speech, Brazilian Team, FIFA World Cup.

1- Uma versão deste trabalho também foi publicada nos anais do GP Comunicação e Esporte do XIV Encontro dos Grupos de Pesquisa em Comunicação, evento componente do XXXVII Congresso Brasileiro de Ciências da Comunicação 2014. 


\section{Os primeiros anos de futebol no Brasil}

São várias as versões sobre o início da prática moderna do futebol no Brasil. A mais aceita é a chegada de Charles Miller a Santos-SP, em fevereiro de 1894, após um período de estudos na Inglaterra. Desde esse que é considerado o marco inicial da disseminação do jogo no país, o esporte se tornou um instrumento de unidade nacional, integrante fundamental da Cultura Brasileira.

Originado em clubes e colégios de classe média da Inglaterra, no princípio do século XIX, o futebol foi instituído de forma definitiva em 1863, com a criação do The Foot-ball Association, órgão que tinha a função de regulamentar e organizar o esporte em terras inglesas. Neste período, a prática do jogo já era vista como um modelador de caráter de jovens da burguesia europeia. Mas, aos poucos, o proletariado foi conseguindo entrar num ambiente dominado até então pelas classes média e alta $^{2}$.

No Brasil, não foi diferente. Praticado, na maioria, por jovens brancos da elite e imigrantes, antes dos anos 1920, as partidas eram criticadas por alguns intelectuais nacionalistas que achavam o futebol mais uma influência estrangeira e alienante do povo brasileiro. Era mais um elemento que colocaria em risco a autenticidade da Cultura Brasileira. Já que o “ser brasileiro” não poderia vir de cópias dos países exteriores.

Com a consolidação do fim da escravatura, a difusão entre as camadas mais pobres e os negros ganha força, já que a prática esportiva em geral sofreu mudanças de valores após a abolição em 1888. Antes, a sociedade brasileira convivia com o preconceito: quem tivesse a pele bronzeada e cravos e trabalhadores comuns. O homem não se preocupava com a aparência física, tinha pele clara e músculos frágeis. Com a libertação dos negros e o crescente uso social dos esportes, isso muda. Mesmo um homem de elite, para se destacar, precisava ter um bom porte físico e praticar alguma atividade esportiva.

No início dos anos 1900, jovens brasileiros que tinham estudado na Europa e imigrantes europeus fundaram os primeiros clubes de futebol no país. Restrito inicialmente à elite, "o foot-ball funcionava como um símbolo de status quo, como diferenciador de classes, um referencial para as pessoas que queriam ter bom gosto e ser aceitos na alta sociedade" (SOUZA, 2008, p.28). À época, o remo e o críquete eram os esportes mais populares, ao menos no Rio de Janeiro. Aos poucos, as cidades foram se transformando. Campos de várzea foram aparecendo em bairros suburbanos. Trabalhadores, pobres, negros e mulatos adotaram o esporte como lazer. Famílias inteiras acompanhavam os jogos. Novos clubes foram criados. E a popularidade do futebol aumentou.

Antes, somente os jovens e as mulheres das elites iam assistir aos matchs. Depois, os espaços nas arquibancadas passaram a ser disputados por um novo público. Trabalhadores e desempregados passaram a olhar com mais interesse a novidade. Todos estranhavam, no início, aquele espetáculo de vinte e duas pessoas correndo atrás de uma bola. Entretanto, existia algo viril, algo de sanguinário, algo trágico nesse jogo que levava aquelas pessoas, sofridas com a vida, a extravasarem seus rancores e desilusões numa partida de foot-ball. (SOUZA, 2008, p.30-31)

A Seleção Brasileira de futebol surge nesse cenário, no ano de 1914. Diante da necessidade de se montar um seleciona- 
do para enfrentar equipes estrangeiras, foi a campo um combinado de jogadores paulistas e cariocas, no Estádio das Laranjeiras, no Rio. A vitória por 2 x 0 sobre $\mathrm{o}$ Exeter City, da Inglaterra, em 21 de julho, inaugurou o que seria considerado posteriormente como "um novo canal formal de operação para a diplomacia das nações" (SARMENTO, 2013, p.12). Esse primeiro jogo foi seguido de diversas disputas contra os vizinhos Uruguai e Argentina. Desde então, as partidas envolvendo a Seleção Brasileira passaram a ser frequentes. E os convites para participar de torneios, principalmente contra equipes da América do Sul, também.

Essa disputa em campo, ainda de uma maneira amadora, porém de suma importância diplomática, colocou o governo brasileiro diante de uma tarefa complicada: unificar as associações regionais que organizavam a prática do futebol no país em um único organismo nacional. Desde a criação da Liga Paulista de Futebol (LPF), em 1901, vários outros órgãos foram fundados, principalmente no eixo Rio-São Paulo. Assim, a disputa política entre essas associações, que atendesse o interesse de todas em torno do "comando" esportivo inviabilizava a formação de uma Seleção com os principais jogadores. Somente em 1916 foi criada a Confederação Brasileira de Desportos, que unificaria a organização do futebol no país ${ }^{3}$. Mas a CBD, mesmo assim, não resolveu de início todos os problemas de relacionamento e interesses de dirigentes, principalmente de Rio e São Paulo.

Após fracassos nos primeiros campeonatos contra os rivais continentais, o Brasil conseguiu vencer seu primeiro título em 1919, no Sulamericano disputado no Rio de Janeiro. Esses primeiros anos do fute- bol brasileiro foram marcados pelo amadorismo. Inicialmente, os jogadores não recebiam salários. Contudo, uma prática escondia um certo pagamento aos atletas. O "bicho" - uma ajuda de custo por partida - era pago por vitória. Uma espécie de salário informal. Com isso, jogadores das classes mais baixas viram uma maneira de ascensão. O profissionalismo seria inevitável, mesmo sendo alvo de muitas críticas. O jogador que recebia algum valor por partida era considerado "mercenário". O amadorismo era exaltado, pois o atleta jogava "por amor à camisa" de um clube. Era um ídolo, apreciado e convidado como estrela em bailes de gala. Sem obrigações trabalhistas. Um dos medos de se instaurar os contratos profissionais era vincular o atleta a um clube com deveres e direitos de trabalhador comum, sem regalias.

Aos poucos, o futebol virara um grande balcão de negócios. Os times que mais venciam, traziam mais torcedores, fãs, visibilidade. As vitórias eram necessárias. Os melhores jogadores eram disputados e recebiam bons "bichos". "Se o atleta não gostasse do ordenado, atuava mal, mudava de time ou viajava para o exterior. Era preciso encontrar uma maneira de manter o bom player no clube. Muitos, revoltados com a sua situação ambígua, exigiam que o profissionalismo fosse reconhecido de fato" (SOUZA, 2008, p.32).

O profissionalismo chegaria de vez nos anos $1930^{4}$. Década que ficaria marcada também pelas primeiras Copas do Mundo. O Mundial foi uma ideia que surgiu logo após os Jogos Olímpicos de 1928, em Amsterdã, na época cidade-sede da Fifa - a Federação Internacional de Futebol Associado, órgão criado em 1904 para reger o futebol no mundo -, quando o atual bicampeão olímpico do esporte, Uruguai,
3- Cf. Sarmento, 2013.

4- Mais especificamente no ano de 1933, quando "o governo instituiu a profissionalização do futebol, superando os limites do profissionalismo marrom que caracterizara o esporte por tantos anos" (AGOSTINO, 2002, p. 142). 
se ofereceu para arcar com as despesas e organização do torneio. Saía do papel o projeto do presidente da Fifa, o francês Jules Rimet, de se criar um torneio autônomo das Olimpíadas, que reunisse seleções nacionais. Estava lançada a competição que evidenciaria as disputas entre nações como um forte sentimento nacionalista, carregada de simbolismos sobre os países que disputam o torneio.

Decidiu-se, pouco depois, no Congresso Internacional da Fifa, que o campeonato seria disputado em 1930, ano do Centenário da Independência do Uruguai, uma maneira de atender o pedido dos representantes uruguaios na entidade de tornar o selecionado um símbolo da nacionalidade, vinculando a imagem de um feito histórico do país ao time de atletas que disputariam a competição. A seleção do Uruguai seria utilizada como representante da identidade nacional, assim como outros países pelo mundo fariam com suas seleções.

\section{Identificação nacional e Seleção Brasileira}

Ao longo dos mais de 120 anos de futebol no Brasil, ao mesmo tempo em que podemos assistir governantes utilizando, num determinado momento histórico, uma vitória esportiva e servindo-se dela como o significante, através do qual transmite mensagens ideológicas, o esporte também é usado por um grupo de operários e trabalhadores de classe baixa para tentar demarcar seus próprios limites.

É o que Simoni Guedes (1977, p. 163) trata o futebol como sendo "instituição zero", ou melhor, como instrumento de significação e representação. "Assim como a identidade nacional, o futebol é invenção e reinvenção de governantes e governados, dominantes e dominados. Espaço de inte- gração e conflito" (SOUZA, 2008, p.26).

Poucos elementos da cultura nacional podem proporcionar à sociedade brasileira a experiência de justiça e igualdade social pregada por Roberto DaMatta (1994, p. 17). Talvez pela facilidade de entendimento de regras e por mostrar que as partidas nem sempre poderiam ser previstas. Sai vitorioso quem tem mais mérito ao longo do jogo.

Vencer em uma Copa do Mundo trazia sentimentos de confiança e esperança ao brasileiro. "Povo que podia vencer como país moderno, que podia, também, finalmente, cantar com orgulho o seu hino, e perder-se emocionado dentro do campo verde da bandeira nacional" (DAMATTA, 1994, p. 17).

Se pensarmos que os traços da identidade brasileira a definem como uma "unidade na diversidade" (ORTIZ, 2012), o futebol também se mostra democrático e plural. Esse elemento aglutinador de raças e classes, conseguiu unir Estado nacional e sociedade. Assim, a preocupação com o universo esportivo se aproximava da defesa dos interesses nacionais, da promoção social do povo e da construção da identidade nacional. $\mathrm{O}$ esporte reafirmou sua condição de meio de expressão das construções imaginárias acerca da identidade nacional. "Artistas, políticos e intelectuais, como o escritor Coelho Neto, manifestaram-se favoravelmente à disseminação da prática desportiva como elemento de ascensão social e de realização das aspirações e projetos relacionados à construção da identidade nacional brasileira" (SARMENTO, 2013, p.32).

Historicamente, o debate em torno da identidade nacional mostra um sincretismo. Diante da disparidade racial, o elemento mestiço foi sendo considerado 
primordial para entendermos o ser brasileiro. A construção da legitimidade de um modelo de representação nacional começou a encontrar no campo desportivo um espaço privilegiado para a veiculação de um imaginário sobre o ideal de brasilidade. Afinal, o esporte estava relacionado à expressão das massas urbanas.

Esse movimento, reforçado na década de 1930, no Governo Getúlio Vargas, vai, no entanto, acentuar o processo de unificação nacional, o que será visto pelo pensamento tradicional como uma tendência "totalitária” que se contraporia à natureza brasileira da unidade na diversidade (ORTIZ, 2012, p.98). Uma vez que se percebera o quanto o futebol era um importante instrumento para influenciar a visão que o brasileiro tinha de si próprio, os esforços governamentais foram ainda mais longe. $\mathrm{O}$ esporte passou a ser encarado pela propaganda getulista como síntese da capacidade e originalidade brasileira (dizia-se que os jogadores reinventaram o jogo bretão), o futebol assumia uma função crucial nos valores ideológicos governamentais.

A presença de negros na seleção passou a ser apresentada como símbolo da democracia racial, ideia que ganhava projeção nos anos de 1930 a partir das teses do sociólogo Gilberto Freyre. Este, autor de uma série de trabalhos sobre identidade nacional e desporto, afirmava que um dos trunfos da Seleção Brasileira era exatamente a mestiçagem, conferindo aos brasileiros um estilo de jogo todo original (AGOSTINO, 2002, p. 143-144).

Esse sincretismo de raças foi exaltado pela primeira vez na Seleção, durante a Copa de 1938, com jogadores negros e mulatos fazendo sucesso na equipe que disputou o Mundial na França. Conferindo características de, enfim, um "futebol brasileiro". A temática racial é reeditada por Freyre, sendo colocada como um privilegiado objeto de estudo para a compreensão do Brasil.

\begin{abstract}
A ideologia da mestiçagem, que estava aprisionada nas ambiguidades das teorias racistas, ao ser reelaborada pode difundir-se socialmente e se tornar senso comum, ritualmente celebrado nas relações do cotidiano, ou nos grandes eventos como o carnaval e o futebol. O que era mestiço torna-se nacional (ORTIZ, 2012, p.41).
\end{abstract}

Uma das tendências do texto do sociólogo seria transformar a "negatividade" que existia sobre o mestiço em "positividade", conferindo contornos de uma identidade que vinha sendo desenhada, inclusive pelo futebol.

Sendo a identidade como uma entidade abstrata sem existência real, ela torna-se indispensável como ponto de referência. Se traduzirmos esta afirmação genérica em termos de identidade nacional, temos que esta, assim como a memória nacional, é sempre um elemento que deriva de uma construção de segunda ordem e que se modificaria no decorrer das diferentes "fases" da história brasileira.

A identidade nacional é uma entidade abstrata e como tal não pode ser apreendida em sua essência. Ela não se situa junto à concretude do presente, mas se desvenda enquanto virtualidade, isto é, como projeto que se vincula às formas sociais que a sustentam (ORTIZ, 2012, p.138).

E através do contraste entre os estilos de jogo dos europeus e dos brasileiros, os intelectuais começaram a associar o futebol com a nação que se pretendia construir. Se, antes de 1938, a ausência da figura do mestiço impossibilitava o Brasil ser pensa- 
do como um todo, com a Seleção Brasileira naquele ano, dos craques negros Leônidas e Domingos da Guia, a identidade nacional se mostra democrática e plural.

A Copa de 1938 foi marcante também porque o entusiasmo que atingia os torcedores nas vitórias, das mais variadas raças e classes, chamou a atenção do governo brasileiro. "Mais do que uma representação positiva da harmonia social, o entusiasmo pelo futebol combinava o nacionalismo e o orgulho cívico, tão defendidos pelo Estado Novo. Era preciso incentivar e controlar essa forma de manifestação social" (SOUZA, 2008, p.70).

A Seleção Brasileira seria o veículo perfeito a dar concretude à idealização de democracia social do Estado Novo. E agora com uma equipe mestiça, representando uma única nação. "Era essencial articular a comunicação entre as elites e o povo, voltar-se para as pessoas humildes em suas mais autênticas manifestações e tradições, sancionando, assim, a tão sonhada integração da sociedade brasileira" (GOMES, 1994, p. 178).

Projetos nacionais para a área desportiva foram implementados pelo regime, instaurado por Getúlio Vargas em 1937, após a boa receptividade da imagem da seleção de 1938 pela sociedade brasileira. De acordo com Sarmento (2013, p. 72), "havia sido consolidado o vínculo simbólico entre o conceito de nação e o desempenho da seleção nacional de futebol. A mestiçagem, o 'mulatismo', o vigor malemolente estavam casados tanto à noção de um ideal de povo brasileiro quanto à sua expressão através de um singular jeito de jogar futebol”.

Os jogadores da Seleção passaram a compreender que nas suas jogadas estavam os anseios e desejos de um povo brasileiro. Estavam cientes do papel de elemento-sín- tese da nação, que defenderiam em cada torneio. Assim, após o Mundial de 1938, o Brasil passou a perseguir a Copa não somente como forma de resolver um dilema simbólico relacionado à identidade étnica e cultural do povo brasileiro.

\section{Maracanazo e o pentacampeonato mundial}

Com o fortalecimento do futebol no país, o Brasil se candidatou a ser sede do Mundial pós-Segunda Grande Guerra. A Copa de 1950 era vista como uma oportunidade de elencar a nação entre as maiores potências do mundo. Com obras grandiosas, como a construção do maior estádio do mundo na época, o Maracanã, o Brasil também se apresentava como candidato ao título dentro de campo.

Após uma campanha com bons jogos e goleadas marcantes na fase final, o que levou a uma euforia e um clima de "já ganhou" antecipado entre imprensa e torcedores, a equipe sucumbiu diante do Uruguai, 2x1, com público de mais de 200 mil pessoas no Maracanã. Os jogadores da Seleção Brasileira ficaram marcados pela derrota, conhecida como Maracanazo. O principal deles, o goleiro Barbosa, acusado de falhar no gol de Ghiggia. A derrota do Brasil despertou um trauma, o que o escritor Nelson Rodrigues chamou de "Complexo de Vira-latas":

Por "complexo de vira-latas" entendo eu a inferioridade em que o brasileiro se coloca, voluntariamente, em face do resto do mundo. Isto em todos os setores e, sobretudo, no futebol. Dizer que nós nos julgamos "os maiores" é uma cínica inverdade. Em Wembley, por que perdemos? Por que, diante do quadro inglês, louro e sardento, a equipe brasileira ganiu de humildade. Jamais foi tão evidente e, eu diria mesmo, espetacular o nosso vira-latismo. Na já citada vergonha de 50, éramos superiores aos 
adversários. Além disso, levávamos a vantagem do empate. Pois bem: e perdemos da maneira mais abjeta. Por um motivo muito simples: porque Obdulio nos tratou a pontapés, como se vira-latas fôssemos. Eu vos digo: - o problema do escrete não é mais de futebol, nem de técnica, nem de tática. Absolutamente. É um problema de fé em si mesmo (RODRIGUES, 1993, p. 51).

O Brasil não conseguiria o título no Mundial seguinte, 1954, mas adotou a camisa amarela como uniforme oficial, o que se tornou símbolo da equipe, aposentando a cor branca dos anos anteriores. Na Suécia, em 1958, surgiria uma geração que daria as primeiras taças ao país. Com craques como Pelé, Garrincha, Didi, Vavá, Nilton Santos, Zagallo entre outros, a Seleção conquistou a primeira Jules Rimet ao vencer o selecionado sueco por $5 \times 2$. Com a mesma base, mas perdendo Pelé para a fase final - Amarildo foi o substituto -, o time venceu a Tchecoslováquia, $3 \times 1$, na final do Chile, em 1962.

Em 1966, decepção. A equipe que tinha Garrincha e Pelé foi eliminada ainda na primeira fase. O "Rei do Futebol" ainda teria uma chance, no México, em 1970, de conquistar o tricampeonato. A equipe comandada pelo técnico Zagallo também reuniu nomes como Gérson, Rivellino, Tostão e Jairzinho. Venceu a Itália na final por $4 \times 1$. É considerada uma das equipes mais brilhantes da história do futebol.

Após a conquista definitiva da taça Jules Rimet, o Brasil passou 24 anos sem título de Copa do Mundo. O tetracampeonato veio em 1994, com Romário, Bebeto e Taffarel nos Estados Unidos, ao vencer novamente a Itália, agora nos pênaltis. Após 1994, a Seleção chegaria ainda a duas finais consecutivas: $3 \mathrm{x} 0$ para a França, em
1998 - até então a maior derrota brasileira em Mundiais em termos de placar - e 2x0 sobre a Alemanha, em 2002, no ressurgimento de Ronaldo, numa equipe que também tinha Rivaldo e Ronaldinho Gaúcho sob o comando do técnico Felipão. Foi o pentacampeonato, último título do Brasil em Copas.

Nos anos de 2006 e 2010, a seleção foi eliminada nas quartas de final. A expectativa era a Copa de 2014, a segunda no Brasil.

\section{A Copa de 2014}

O Brasil foi escolhido sede da $20^{\text {a }}$ edição da Copa do Mundo Fifa em 2007. Ao todo, 12 cidades foram selecionadas para receberem os jogos do torneio. Ao longo da preparação, o Mundial passou a ser questionado por setores da sociedade que viam suspeitas de desvio de verbas públicas nas obras, mau planejamento da organização, atraso em melhorias previstas de infraestrutura e estádios. Esse clima de pessimismo sobre o sucesso do evento no país culminou em movimentos nas redes sociais, como o "Não vai ter Copa!", que tomaram as ruas do país durante a Copa das Confederações - evento-teste para o Mundial - em junho de 2013. Até o início do torneio, ainda era difícil prever qual Copa teríamos, como seriam os resultados deste misto de insatisfação da população e problemas estruturais.

Os estádios foram entregues no último prazo, algumas obras de infraestrutura ficaram pelo caminho, mas o Mundial teve uma repercussão boa dentro e fora do país. A própria imprensa adotou a expressão "Copa das Copas", que reverenciava o sucesso fora dos gramados e a qualidade dos jogos.

Dentro de campo, a Seleção Brasileira 
5 - Para essa análise, vamos utilizar, como influência, um autor da Análise do Discurso Francesa. A AD é compreendida em diferentes vertentes, cada uma com suas respectivas categorias de análise. Parte-se aqui em busca das categorias que prestam-se mais adequadamente ao escopo pretendido. Entre as variantes dessa tradição, pretendo desenvolver um dispositivo analítico influenciado pelo estudo de Henri Boyer que trabalha questões relacionadas à construção de estereótipos, emblemas e mitos no discurso das mídias. Para ele, o sentimento de identificação é operado num discurso de representações compartilhadas dentro de uma determinada comunidade nacional. O impac to sobre a ação dos indivíduos e dos grupos e seu discurso é afirmado pelos "estereótipos". O estereótipo é considerado aqui como uma espécie de representação instaurada em todos os pertencentes a uma comunidade (ou um grupo dentro da comunidade). É, portanto, uma estrutura sociocognitiva fixada. Os estereótipos, inegavelmente, têm uma função identitária em uma determinada comunidade. Não apenas os atletas da Seleção Brasileira podem ser estereotipados, já que o termo não é apenas usado para representar grupos humanos. O futebol, em si, o país, espaços urbanos, comportamentos etc. podem ser figurados.

O emblema também opera em atores (por exemplo: Ronaldo, o "Fenômeno") e em produtos cul turais (a Seleção "Canarinho") que representam um sentimento de identificação com um grupo de pessoas. A própria Seleção, portanto, pode ser um emblema do Brasil.

O mito seria reforçado pela mídia ao vincular histórias e características a um determinado feito/pessoa produzindo sentido identitário. As campanhas da Seleção Brasileira em Copas do Mundo, em parte, são mitificadas pelas mídias. Como exemplo, temos as derrotas nos Mundiais de 1950 e 1982, conhecidas como "Maracanazo" e "Tragédi do Sarriá", respectivamente.

Além das conquistas e a história mitificada de craques como Pelé, Garrincha, Romário e Ronaldo e como esses atletas tornam-se heróis nacionais. Boyer (2008) trata dessas características na imprensa francesa.

Portanto, deve-se observar a construção de mitos na derrota de $7 x 1$ para a Alemanha, na Copa do Mundo de 2014, mas com os emblemas e os estereótipos adotados nos discursos, para legitimar o uso da Seleção Brasileira como instrumento simbólico de identidade nacional. chegou cercada de expectativa por manter a equipe que vencera a Copa das Confederações no ano anterior. $\mathrm{O}$ time venceu na primeira fase Croácia $(3 \times 1)$ e Camarões $(4 x 1)$ e empatou com o México (0x0). Classificou-se em primeiro do grupo. $\mathrm{Na}$ fase eliminatória, eliminou dois adversários sulamericanos: Chile, nos pênaltis, e Colômbia (2x1). Nesta partida contra os colombianos, o maior destaque da seleção até então, Neymar, sofreu uma joelhada nas costas, quebrou uma vértebra e desfalcou o Brasil no restante do Mundial. A semifinal, já sem Neymar e o capitão Thiago Silva - suspenso por receber o segundo cartão amarelo -, era contra a Alemanha. O jogo em Belo Horizonte, no dia 08 de julho de 2014, entraria para a história do futebol brasileiro como a maior derrota em cem anos de Seleção Brasileira: 7x1. O Brasil ainda perderia a disputa de terceiro lugar para a Holanda, 3x0, e amargaria o quarto lugar em casa. $\mathrm{Na}$ final, a Alemanha venceria a Argentina por 1x0, na prorrogação, e conquistaria o tetracampeonato.

\section{A derrota para a Alemanha na Fo- lha de S.Paulo e $O$ Globo}

A derrota para a Alemanha foi manchete nos principais jornais do país e do mundo. Para este trabalho, vamos analisar os textos da Folha de S.Paulo e do O Globo, na edição de 09 de julho de $2014^{5}$.

O principal estereótipo instaurado na Seleção Brasileira é de uma equipe fracassada, que causou ao país vexame maior que a, até então, mais traumática derrota em Copas. Como vemos na manchete de capa da Folha: "Seleção sofre a pior derrota da história - Alemanha faz 7 a 1, esmaga Brasil e está na final da Copa - País revive trauma de 1950 como anfitrião - Scolari assume responsabilidade por vexame, o maior em 100 anos" (FOLHA, 09/07/14, capa). Ou ainda: "Se em 1950 o 2 a 1 para o Uruguai teve contornos trágicos, a eliminação de 2014 foi marcada pela humilhação. A seleção conheceu a maior derrota de sua trajetória centenária e o pior revés de um anfitrião de Mundiais" (FOLHA, 09/07/14, capa).

O caderno especial "Copa 2014" chama a partida de "O pior vexame", "Catástrofe", "O maior vexame da sua história" (FOLHA, 09/07/14, p. D2). Os jogadores são ligados a expressões que remetem a insucesso, fracasso, como o artigo "O inferno de Dante" (FOLHA, 09/07/14, p. D4).

N'O Globo a abordagem não foi diferente. No caderno especial "Copa 2014", uma sequência de manchetes: "BRASIL 1 X 7 ALEMANHA - ESTA SELEÇÃO FEZ HISTÓRIA - A pior derrota em 100 anos da equipe - $\mathrm{O}$ pior revés de um anfitrião de Mundial - A maior goleada em uma semifinal - A pior derrota de uma seleção campeã - O maior vexame do futebol brasileiro - OS JOGADORES DE 1950 ESTÃO REDIMIDOS”. A comparação com a geração derrotada da primeira Copa no país e a constatação de uma crise, um futebol brasileiro em decadência está em trechos como:

Antes que as vaias merecidamente destinadas a Fred revivam o ritual sumário que condenou Barbosa, chegou o momento de inverter o processo. Numa Copa em que o Brasil jogou nada do primeiro ao último jogo, os jogadores devem ser vistos como a consequência e não a causa do vexame. Todos lutaram contra suas limitações, uns sucumbiram às lágrimas e todos tombaram diante da constatação de que já não temos forças para disputar entre os melhores. [...] Depois que a natureza deixou de produzir craques feito capim, no vão da sociedade onde havia espaço para o improviso, a necessidade de um cultivo sistemá- 
tico e científico compara o futebol brasileiro a um vinhedo esgotado. De tanto antecipar a colheita, a safra se tornou cada vez mais verde e sem personalidade. O tempo de maturação em casa, além de concluir a formação na cultura local, fazia crescer todo o jogo coletivo. Com o êxodo prematuro, o brasileiro passou a jogar como os demais sem ter uma referência doméstica para preservar os princípios de uma escola de excelência. No lugar do trabalho para atualizar os métodos, restaram as mesmas bravatas que remetem a 1950 . Se naquela ocasião, o prefeito Mendes de Morais saudou os campeões antes do último jogo, dessa vez foi Parreira quem disse que o Brasil já tinha uma mão na taça enquanto Felipão prometia a conquista (O GLOBO, 09/07/14, p.4).

O estereótipo também é de uma equipe que não teve sucesso e que sofrera "A vergonha das vergonhas na Copa das Copas", como diz o artigo de Renato Maurício Prado (O GLOBO, 09/07/14, p. 6). Ou no texto "Pororoca de recordes - Desonra Amarela":

Levou, como o placar eloquente comprova, um baile constrangedor, que expõe o profundo atraso em que o país está metido, justamente em seu esporte mais popular. [...] Barbosa, afinal, pode descansar em paz. O futebol brasileiro tem vexame maior para velar (O GLOBO, 09/07/14, p. 6).

Os jogadores não receberam alcunhas, mas notas baixas da equipe da Folha em relação ao desempenho no jogo que variaram entre 0 e 2. Já O Globo atribui adjetivos aos atletas, que receberam todos nota zero: "Júlio César - Soterrado; Maicon Atropelado; Dante - Perdido; David Luiz - Atarantado; Marcelo - Enrolado; Luiz Gustavo - Derrubado; Fernandinho Desgovernado; Paulinho - Superado; Os- car - Fraco; Hulk - Atabalhoado; Ramires - Irrelevante; Bernard - Equivocado; Fred - Trágico; Willian - Insípido; Felipão - Vencido" (O GLOBO, 09/07/14, p. 6). A atuação do goleiro Júlio César, inclusive, foi criticada em uma matéria da Folha com um casal de aposentados, com o título "Foi mais vergonhoso que 50, diz casal formado no Maracanazo": "Falaram tanto do Barbosa [goleiro brasileiro na derrota de 50], que levou dois, e esse aí [Júlio César] levou sete", lamentava [Gabriel Ferreira da Silva, 89 anos] (FOLHA, 09/07/14, p. D16).

Quanto à ligação da seleção de futebol como emblema do Brasil, a Folha demonstra o desgaste dessa representação na sua editoria de Opinião, em um dos editoriais, com o título "Pátria sem chuteiras":

Derrota brutal da Seleção Brasileira diante da Alemanha talvez possa representar o fim de uma era dentro e fora do futebol . [...] O vexame histórico, ainda que não numa final de campeonato, vem eclipsar o famigerado 'maracanazo' de 1950. [...] A frustração - mas o termo é leve demais para descrever o que aconteceu - talvez possa, com o tempo, enquadrar-se num contexto diverso daquele que marcou, até hoje, as relações do brasileiro com seu esporte mais popular. [...] Já constituía um fenômeno curioso que, no chamado país do futebol, tenham se observado movimentos expressivos, ainda que isolados, de oposição a que a Copa do Mundo se realizasse por aqui. [...] A ideia de uma 'pátria em chuteiras', na célebre formu- 
lação de Nelson Rodrigues, terá provavelmente sofrido um subterrâneo desgaste ao longo dos anos. Um país mais diversificado, plural e rico foi deixando de ver, nos campos de futebol, sua única fonte de compensação diante dos muitos insucessos do seu projeto econômico e social. [...] Injustificado, talvez, tenha se provado o hábito de depositarmos tanto de nossa identidade nacional num único esporte, num único campo, num único jogo - que sempre é o de hoje. [...] A paixão futebolística sobreviverá, é claro, ao pesadelo de ontem. Mas o massacre, no que teve de brutal e inesquecível, não maculou apenas a mística da camisa verde-amarela; talvez venha a significar também o encerramento de uma época em que país e estádio, povo e torcida, governantes e técnicos, nação e seleção tendem a ser vistos como a mesma coisa. [...] Talvez se possa dizer, a partir de agora, que o Brasil é maior que seu futebol - e que tem desafios mais importantes, e maiores, a vencer. (FOLHA, 09/07/14, p. A2).

O Globo trouxe a questão emblemática do "esporte-nação", mas reforçando essa ideia de simbolismo de um pelo outro, em uma entrevista com o antropólogo Roberto DaMatta:

Então, o futebol é a construção nacionalista mais natural brasileira?

Eu não diria que é natural, mas é a construção nacionalista moderna do Brasil. O futebol foi inventado pelos ingleses, que eram os caras puros, sérios e brancos, mas nós o roubamos. Esse país de mulatos, de negros, de gente de perna torta, que era considerado um país de analfabetos, foi lá e dominou o futebol. [...] O futebol, portanto, trouxe ao Brasil um elemento moderno que fez com que nós acreditássemos em nós mesmos. Isso não tem preço (O GLOBO, 09/07/14, p. 12).

Quanto às histórias contadas sobre a partida na imprensa, o que contribui para a construção de mitos, a Folha de São Paulo representou o comportamento dos torcedores e os momentos que marcaram os 90 minutos da partida, como na reportagem "No limite - Brasileiros empurram time até início de goleada; depois vaiam, brigam entre si e deixam estádio antes do final":

A sequência de gols da Alemanha no primeiro tempo não deu tempo para a torcida brasileira, maioria entre os mais de 58 mil torcedores, se recuperar, perplexa, do que assistia. Entre $11 \mathrm{~min}$ e $22 \mathrm{~min}$, um ou outro canto de apoio do estádio ainda surgia. [...] Os brasileiros, então, aplaudiram os alemães. Veio o gol de Oscar e o estádio ainda vibrou, mas logo as vaias voltaram. Ao fim da partida, mais vaias para jogadores e comissão técnica da seleção, reunidos no centro do campo (FOLHA, 09/07/14, p. D16).

Ou no texto "Fogo na capela":

Tá duro assistir ao Mineirão lotado e perplexo. Depois de quatro gols em seis minutos, engolimos a seco o "Eu acredito!" e passamos a desejar secretamente, ardorosamente, que nos fechássemos numa pusilânime retranca para não perder de dez, de 20. Foram sete. Sete! E poderia ter sido mais (FOLHA, 09/07/14, p. D23).

A atitude dos torcedores na arquibancada também foi destaque n'O Globo, na reportagem "Na arquibancada - Sobrou a bronca": "Depois de Oscar balançar a rede 
no fim, um coro irônico ecoou entre os brasileiros: 'Eu acredito'. Foi o retrato de uma derrota que não teve o silêncio do Maracanazo, em 1950. Dessa vez, a reação foi mais de espanto do que de choro" (O GLOBO, 09/07/14, p. 7).

O jornal O Globo, em sua capa, fez uma analogia com a derrota de 1950 e o Maracanazo, criando uma nova expressão para denominar os 7 a 1: "Mineiratzen". Seguida da manchete: "Vergonha, vexame, humilhação - Em menos de meia hora Alemanha faz 5 gols e massacra Brasil com placar final de $7 x 1$; seleção sofre em casa a maior derrota da história" (O GLOBO, 09/07/14, capa).

O jornal ainda representa a semifinal com textos críticos à Seleção Brasileira e projetando mudanças no comando da equipe. Fernando Calazans aponta como "Uma única saída: ressuscitar":

O futebol brasileiro pentacampeão do mundo, os donos dos cinco títulos - jogadores, técnicos, torcedores de todas as épocas - não mereciam isso. Não mereciam saber disso, muito menos ver isso, presenciar isso, assistir a isso. Não mereciam passar por essa vergonha, essa tragédia - e, vou dizendo logo, uma tragédia maior, muito maior, do que a vivida no $\mathrm{Ma}$ racanã, na Copa de 1950, quando perdemos o título para o Uruguai, por 2 a 1. [...] Não tem comparação. Quem imaginava que um dia fôssemos nos redimir daquela derrota, na primeira Copa realizada no Brasil, se sente, agora, na segunda, mais desencantado do que nunca, com a derrota de 7 a 1 para a Alemanha na semifinal. E quem achava que, lá atrás, tínhamos passado por uma vergonha simplesmente não sabe o que dizer. Ou talvez saiba: uma humilhação. [...] O futebol brasileiro - aquele dos cinco títulos mundiais - só tem uma única saída: ressuscitar. Não há forma de remissão, de recuperação, de reação. $\mathrm{O}$ futebol brasileiro tem que nascer de novo. Tem que renascer. Para quem foi, para quem é pentacampeão do mundo, para quem tem um lugar definitivo na História, não deve ser impossível. [...] Esse jogo, essa derrota, essa goleada histórica tem que ser guardada na memória, para marcar o início de uma era de total reformulação (O GLOBO, 09/07/14, p.2).

A reportagem principal sobre o jogo, assinada pelo jornalista Pedro Motta Gueiros faz ligação entre as duas derrotas nas Copas em casa, mas mitificando os 7 a 1 como a pior derrota brasileira em todos os Mundiais.

\section{DURO GOLPE 64 ANOS DEPOIS -} EM ESCOMBROS

Vexame que torna honrosa a derrota de 1950 suscita debate para que o futebol brasileiro recupere a identidade perdida junto com as linhas de um Maracanã que foi reformado para a festa alheia.

O barulho do silêncio, que ecoou no Maracanã depois da derrota de 1950, soava inexplicável para quem não testemunhou aquela jornada, até que a explosão de gols da Alemanha trouxe um vazio apaziguador no Mineirão. Depois de quase sete décadas condenadas ao limbo, as almas dos vice-campeões enfim se libertaram. Ao longo dos 90 minutos em que as ilusões do hexa se espatifaram contra o muro da realidade, a tragédia de 1950 se transformou definitivamente numa derrota honrosa (O GLOBO, 09/07/14, p.4).

A história contada pelos jornais remonta a uma derrota mais traumática do que 1950, uma jornada mitificada pelo discurso dos dois jornais.

\section{Conclusões}

O futebol no Brasil, desde a sua chegada, é considerado uma expressão cultural que vai além do campo esportivo. A Seleção Brasileira, que completa 100 anos em 2014, foi, ao longo dos anos, transformada em fundamental instrumento unificador e identitário da nação. Os cinco títulos mundiais e derrotas marcantes em Copas, his- 
tórias que envolvem não só o resultado dentro dos gramados, mas a ligação entre o ser brasileiro e a representação do selecionado nacional, também contribuíram para esse processo.

A principal derrota do país, antes de 2014, era considerada o Maracanazo, o revés de 2x1 para o Uruguai em 1950. Com a segunda chance de receber o torneio, criou-se uma expectativa de "vingar" esta perda e conquistar o título em casa. Com a vitória da Alemanha, num jogo que quebrou todos os recordes negativos da Seleção Brasileira, os principais jornais do país e do mundo destacaram a goleada por 7 a 1 . Dentre os impressos de maior circulação e renome nacional, destacamos a cobertura da Folha de S. Paulo e O Globo.

Esses dois periódicos representaram a seleção com o estereótipo de uma equipe fracassada, que falhou diante dos seus torcedores. Mesma atribuição foi feita aos jogadores, questionados nos textos, junto com representantes da comissão técnica e da co- ordenação da Confederação Brasileira de Futebol. Uma representação com escolhas semânticas que tendem a afastar o torcedor desta equipe.

Essa temática também é vista quando analisamos a questão da seleção como emblema da nação. O discurso é de desvinculação, usando expressões que indicam que o Brasil não seria mais o "país do futebol".

O mito da semifinal contra a Alemanha é construído pelo discurso dos jornais como a maior derrota da equipe em cem anos, superando o 2x1 para o Uruguai em 1950. Elementos no texto tratam a história da partida como um vexame, um trauma para os brasileiros. Mesmo com a derrota acachapante e o fim do sonho da conquista do hexacampeonato, o discurso dos jornais foi no sentido de afastamentos identitários do brasileiro em relação à seleção. Uma escolha que pode influenciar numa eventual perda de identificação entre torcedores e equipe.

\section{Referências bibliográficas}

AGOSTINO, Gilberto. Vencer ou morrer: futebol, geopolítica e identidade nacional. Rio de Janeiro: FAPERJ: Mauad, 2002.

ARAÚJO, Flávio. O Rádio, o Futebol e a Vida. São Paulo: Editora Senac, 2001, p.174.

BOYER, Henri. Stéréotype, emblème, mythe. Sémiotisation médiatique et figement représentationnel. Mots. Les langages du politique [en ligne], 88 |2008, mis en ligne le 01 novembre 2010. URL : http://mots.revues.org/index14433.html. Acesso em 10 de julho de 2014.

DAMATTA, Roberto. "Esporte na sociedade: um ensaio sobre o futebol brasileiro", in DAMATTA, Roberto; FLORES, Luiz F. B. N.; GUEDES, Simoni L. \& VOGEL, Arno. Universo do futebol: esporte e sociedade brasileira. Rio de Janeiro: Zahar, 1982, p. 19-42.

. Antropologia do óbvio: notas em torno do significado social do futebol brasileiro. Revista USP, São Paulo, n. 22, 1994, p. 10-17.

FOLHA DE S.PAULO, edição 31.143, São Paulo, 09/07/2014.

FREYRE, Gilberto. Football mulato. Jornal Diário de Pernambuco, 17 de junho de 1938. . Casa-Grande \& Senzala. 34ª ed. Rio de Janeiro: Record, 1998.

GOMES, Ângela C. A invenção do trabalhismo. Rio de Janeiro: Relume Dumará, 1994. 
GUEDES, Simoni L. O futebol brasileiro: instituição zero. Rio de Janeiro: Universidade Federal do Rio de Janeiro, Dissertação de Mestrado, 1977.

HOLLANDA, Sérgio Buarque de. Raízes do Brasil. 26a ed. São Paulo: Companhia das Letras, 1995.

O GLOBO, edição 29.556, Rio de Janeiro, 09/07/2014.

ORTIZ, Renato. Cultura brasileira e identidade nacional. 5ª ed. São Paulo: Brasiliense, 2012.

RODRIGUES, Nelson. À sombra das chuteiras imortais. São Paulo: Cia. das Letras, 1993. SARMENTO, Carlos Eduardo Barbosa. A construção da Nação Canarinho: uma história institucional da Seleção Brasileira de futebol, 1914-1970. Rio de Janeiro: Editora FGV, 2013.

SOUZA, Denaldo Achorne de. O Brasil entra em campo! Construções e reconstruções da identidade nacional (1930-1947). São Paulo: Annablume, 2008.

Estudos em Jornalismo e Mídia está sob a Licença Creative Commons 2.5 